\title{
Retailer's perception of impact of ASEAN Economic Community on the growth of Vietnam retail market: A cognitive approach
}

\author{
BUI THANH TRANG ${ }^{a}$, NGUYEN CONG DUNG ${ }^{b}$ \\ $a, b$ University of Economics Ho Chi Minh City
}

\begin{abstract}
A R T I C L E I N F O
A B S T R A C T

Received: 16 Sep, 2016

The research aims to investigate retailer's perceptions of impact of Revised: 28 Oct, 2016

Accepted: 8 Oct, 2018

Available online

JEL classification:

F12, L11, F62

ASEAN Economic Community on the growth of Vietnam retail market. The research is conducted by qualitative and quantitative methods. A sample size is 271 retailers including the retail companies, grocery stores, supermarkets, trade center and convenience store chains. The Cronbach's alpha, exploratory factor analysis and multiple regressions models are used to test the research hypotheses. The results reveal that retailer's perception of the impact of ASEAN Economic Community which focuses on four factors such as: (1) Free trade, (2) investment attractiveness, (3) competitive pressure, and (4) competitiveness of small and medium enterprises have significantly positive relationship with the growth of retail sector. The results also suggest the managerial implications to develop Vietnam retail market.
\end{abstract}

\section{Keywords}

Retailer's perception;

Retail market.

\footnotetext{
a Email: trangbui@ueh.edu.vn, *Corresponding Author.

b Email: ncdung@ueh.edu.vn

Please cite this article as: Bui, T. T., \& Nguyen, C. D. (2018). Retailer's perception of impact of ASEAN Economic Community on the growth of Vietnam retail market: A cognitive approach. Journal of Asian Business and Economic Studies, 25(S02), 47-65.
} 


\section{Introduction}

The Vietnam retail market is highly dynamic and potential, with an average annual revenue growth of $11.7 \%$ for the period 2008 - 2015 (PricewaterhouseCoopers, 2015). Vietnam's retail sector is booming. In 2017, the country ranked sixth in the Global Retail Development Index (GRDI), five places higher than the ranking of the previous year (A.T.Kearney, 2017). Within the ASEAN region, Vietnam is the market with the second highest index after Malaysia. With a relatively small size and a retail market attractiveness index of 26.7, Vietnam is considered a prime market with low saturation. Vietnam's retail value reached US\$130 billion in 2017, a 9.7\% increase compared to the previous year. This growth has been consistent over several years and is expected to keep accelerating at a $10.3 \%$ growth rate per annum until 2020 when the retail market is anticipated to reach US\$170 billion (EU-Vietnam Business Network, 2018). Multinational retailers such as Lotte, Big C, Aeon, Circle K, and 7-Eleven are taking advantage of Vietnam's emerging retail market and have already established their footprints. The presence of foreign retailers in Vietnam creates more competition for domestic retailers (EU-Vietnam Business Network, 2018). Since Vietnam joined the WTO and opened the way for $100 \%$ foreign-owned retailers, the country's retail market has become increasingly lucrative. Traditional retail will remain Vietnam's dominant retail channel in the near future, currently accounting for $68 \%$ of the retail market. Up to now, retail sector is witnessing a shift from traditional retailers to modern retailers with more convenience stores, supermarkets, hypermarkets, and shopping centres. There are so many world-class retail groups entering the Vietnam retail sectors through franchising, joint ventures, direct investment, mergers and acquisitions.

One of the reasons for the growth of retail industry is that Vietnam has entered the period of international economic integration through the signing of bilateral and multilateral Free Trade Agreements (FTAs). Viet Nam has actively participated in ASEAN Economic Community (AEC), and so far ASEAN has become one of the leading trade partners of Vietnam. Since January 2015, thanks to the accession to the WTO, Vietnam's retail sector has been liberalised. Vietnam now allows retailers with up to $100 \%$ foreign capital to set up a business entity. However, the Vietnamese government still maintains two entry barriers, which are the Economic Needs Testing (ENT) process and a list of nine classes of goods that foreign companies are not permitted to distribute.

There are a lot of studies which has analysed and evaluated the effects of FTAs on the economy under the General Equilibrium Models, for example the studies of Todsadee et al. (2012), Petri et al. (2012), Itakura and Lee (2012), and Cheong (2013). All of those studies concluded that most of the countries signing FTAs having more benefits from growth of GDP and increased trade. In particular, Vietnam is a country with a higher rate of change in GDP than other economies in the block, exports increase rapidly, and attracts more foreign direct investment (FDI). 
Baier and Bergstrand (2002) applied the gravity model in analyzing and evaluating the impact of FTAs resulting in a fourfold increase in trade. Carrere (2003) used the results of a study by Baier and Bergstrand (2002) to show that there is a significant increase in trade compared to the data in previous studies. Urata and Okabe (2007) continued to use the gravity model to study the effects of FTAs in East Asia showing rapid increases in trade flows. All studies showed the generally positive effects of FTAs on the economy and trade.

To study the growth of the Vietnamese retail market under the impact of the AEC, the research follows the cognitive approach. This study focuses on the retailer's perception of the impact of the AEC which based on the four factors, (1) free trade, (2) investment attractiveness, (3) competitive pressures, and (4) competitiveness of small and medium enterprises (SMEs) on the growth of the Vietnam retail market. The research objective is to investigate retailer's perception of impact of AEC on retail growth in order to make policy recommendations to enhance the retail sector.

\section{Literature review and hypotheses}

\subsection{Retail and the growrh of retail market.}

Retailing encompasses the business activities involved in selling goods and services to comsumers for their personal, family, or household use. Retailing is an important field to study because of its impacts on the economy, its functions in distribution, and its relationship with firms selling goods and services to retailers for their resale or use (Barry et al., 2018). Retailers use customer-centered, chain-based approaches to develop and implement strategies, with four basic principles: customer orientation; value driven; coordinated efforts; and goal orientation (Barry et al., 2018). McNair (1958) propounded the theory of the Wheel of Retailing. This theory explains a cyclic retail evolution pattern, which he had observed with the European and U.S. organized retail organizations. The Wheel of Retailing is the most frequently cited theory of subsequent researchers. The Wheel of Retailing theory states that the evolution process comprises three stages: entry stage, tradeup stage, and vulnerable stage. This theory is diagrammed as a large wheel with three spokes dividing the wheel into three segments or stages. The entry stage of the Wheel of Retailing starts with offering limited merchandise with low prices and retail organizations as a strategy to increase penetration of the market even though low margins are achieved. As the store progresses in its growth, the organization enters the second stage, which is the trade-up stage where the organization offers full services and a range of merchandise in full prices, without any discounts. According to the study by Bennett and Cooper (1981), these firms have highest profits and a strong cash flow. In the third stage, according to the Wheel of Retailing theory, the wheel turns as the store matures in its growth and faces more competition too. Upon reaching this stage, the retailer will reduce prices and scale down services in order to reduce operating costs. In this phase of evolution as McNair (1958) calls "a vulnerable phase as competition may make easy inroads", the strategy is to drop prices. 
According to Bennett and Cooper (1981), continuous innovations and management practices will help the retailer to sustain growth in this phase.

According to Kotler and Armstrong (2012), the basic concept of the wheel of retailing theory defines the process in retail marketing, explaining how a new retail chain is established. After a period of improving the services and products, the chain is acquired by other larger retail chain, leaving its niche market to be filled by the newer discount retailer. A new retailer often enters the market with low status, low profit margin. The later retailer broadens its customer base and is able to sell higher quality products and add more services and increase sales. A new competitor with low price, low margin, low status continues the same evolutionary process. The wheel keeps on turning department stores, supermarkets, and mass merchandise through the same cycle of retail development (Kotler and Armstrong 2012). With the rapid development of the Internet and retail technology, retailing not only includes traditional offline sales in stores but also online business and omni-channel. Retail can be viewed from many different perspectives. It includes the sale of tangible and intangible goods, non-used stores, and can be operated by manufacturers and others, as well as retailers (Barry et al., 2018).

The assessment the growth of the retail sector is based on indicators such as the annual growth rate of retail sales, average annual retail spending, the development of modern retail channels, and the growth of e-commerce in retail. A.T.Kearney (2017), the rating of retail market attractiveness and potential is based on the Global Retail Index (GDRI) with many criteria, two of them are often used to measure the growth of the retail market: (1) average annual retail spending is more than 9\%; and (2) the modern retail channel is account for $20 \%$. These two indexes of the Vietnamese retail market are over $12 \%$ and $26 \%$ respectively, proving that the retail market is growing (A.T.Kearney, 2010; 2017). Vietnam's GDRI in 2016 is 50.8 at 11, and 2017 at 56.1, ranked sixth in the list of 30 countries in the world with high attractiveness of the global retail market. The rapid development of the Vietnamese retail market has come from the process of international economic integration in which Vietnam has signed FTAs and participated in the AEC.

\subsection{Free Trade Agreement and ASEAN Economic Community}

Preferential trading agreements, such as FTAs have both positive and negative effects. An FTA is a commitment by signatory members to remove tariffs across member states while continuing to maintain independent tariff regimes on imports from outside countries (countries that are not members of the agreement). A customs union goes one step further by uniting tariff regimes. Beyond a customs union, there is also a commitment to provide free flows of not only goods and services but also factors of production (labor and capital), which is called a "common market" (Plummer at el., 2010). Some of the most important dynamic effects in the context of FTAs are trade liberalization, trade facilitation creating economies of scale and variety, technology transfer and foreign direct investment (FDI), and structural policy change and reform, as well as competitiveness and long-run growth effects 
(Plummer, 2007). By creating a larger market for firms operating in partner countries, an FTA will allow producers to take advantage of a larger customer base and hence, produce at a lower average cost on all sales. Firms will even be able to lower prices for existing customers - the "cost-reduction effect". As a result, the firms will become more competitive not only at home but also in foreign markets. Customers in each member country will also enjoy more variety in terms of the goods they can purchase because the larger market created by the FTA allows firms to sell in more markets and, given economies of scale, introduce new varieties that were too costly and unprofitable before the FTA (Baier \& Bergstrand, 2007).

Bilateral and regional FTA formation attracts long-term, risk-sharing investment flows by creating a more integrated marketplace within which multinational corporations can enjoy a regional division of labor with low transaction costs and exploit economies of scale. The patterns of FDI that follow the creation of an FTA may be similar to the effects of trade creation and trade diversion. The multinational corporations that believe an FTA will lead to greater economic dynamism may be compelled to invest more in one of the members, thus resulting in "investment creation." An FTA may induce more FDI flows into the region by multinationals that have headquarters outside the region (Baldwin, 1989).

Two models commonly used in assessing the impact of trade policy are the general equilibrium model (GE) and gravity model. The GE models are used for ex-ante analysis, and gravity models used for ex-post analysis. Since these models produce quantitative results that are clear and exact, policy makers can easily assess who gains and who loses from an FTA (Plummer at el., 2010). All researchers concluded that trade liberalization will eliminate tariffs, trade facilitation, creating the significant growth of goods and services exchange, increasing investment, and attracting the intra-regional and outside block investors. Another approach that this paper focuses on is to study the retailer's perception of the impact of AEC on the growth of Vietnam retail market.

The AEC is built on four interrelated and mutually-reinforcing pillars: (1) A single market and production base: free flow of goods, services, investment, capital and skilled labor; promoted integration; gradually eliminated tariffs and non-tariff barriers; (2) A highly competitive economic region: gradually perfected competition policy frameworks, consumer protection and intellectual property rights, developing infrastructure, expanding e-commerce, promoted fair competition culture; (3) A region of equitable economic development: small and medium enterprises development, active integration to narrow the development gap within ASEAN; and (4) A region fully integrated into the global economy: close linkages between ASEAN and other organizations and partners, actively contributing to the global network (AEC, 2015).

The realisation of AEC will see the transformation of ASEAN into a single market and production base that will enhance ASEAN's competitiveness. The AEC will foster the regional integration of priority sectors and allow the free movement of business people, skilled labour and talents. An ASEAN single market and production base comprises five 
core elements: free flow of goods; free flow of services; free flow of investment; free flow of capital; and free flow of skilled labour. Tariffs will be eliminated, and non-tariff barriers will be gradually phased out. ASEAN investors will be free to invest in all sectors throughout the region. There will be a free movement of professionals and skilled labour. Simple, harmonised and standardised trade and customs requirements are expected to reduce transaction costs. A single market for goods and services will boost the development of production networks in the region and enhance ASEAN's capacity to serve as a global production centre to better meet the demands of the global supply chain (AEC, 2015).

Based on previous studies, this papper investigates retailers' perceptions about the impact of the AEC based on four factors, (1) free trade, (2) investment attractiveness, (3) competitive pressure, and (4) competitiveness of SMEs on the growth of retail market.

\subsection{Free trade from AEC and growth of retail market}

The AEC was established in 2015. Since then, steps to improve trade facilitation, including the removal of non-tariff trade barriers to promote the free movement of goods in the region, have been taken to enhance trade among ASEAN Member States (AEC, 2011). To achieve this, the ASEAN Economic Ministers agreed in August 2007 to enhance the Common Effective Preferential Tariff for ASEAN Free Trade Agreement (CEPT-AFTA) to make it a more comprehensive legal instrument. To realize the objective of eliminating nontariff barriers, the provisions on non-tariff measures in the ASEAN Trade in Goods Agreement (ATIGA) have been enhanced further through codification of measures and the establishment of a mechanism to monitor the committed elimination of non-tariff barriers. The ATIGA also includes the ASEAN framework on trade facilitation. As a result, the AEC promotes free movement of goods and services in the region. AEC creates opportunities for two-way trade between Vietnam and its partners, which will create favorable conditions for the retail market to develop.

There were many studies evaluating the impact of FTAs on trade in services. Francois (2001) was one of the first studies to use a gravity model for service. The next studies were of Park (2002), Grunfeld and Moxnes (2003), Kimura and Lee (2006), Lejour and Verheijden (2004), Mirza and Nicoletti (2004), Kox and Lejour (2005), Lennon (2006). All studies concluded that trade liberalization will eliminate tariffs and facilitate trade, resulting in a significant growth in the flow of goods and services. Nguyen et al. (2015) and Nguyen (2012) studied the impact of the AEC on Vietnam trade and shown that the impact of AFTA on trade and services in ASEAN had a positive impact on Vietnam export and import. The import of goods and services from ASEAN countries are higher than Vietnam exports to ASEAN. The potential economic impact of the AEC will depend on the factors, including the extent of trade liberalization achieved in the agreement, as well as the current and potential growth of trade including retailing and investment among AEC members. Therefore, we deem it appropriate to assume that:

$H_{1}$ : There is a positive relationship between retailer's perception on free trade from AEC and growth of retail market. 


\subsection{The investment attractiveness from AEC and growth of retail market}

ASEAN aims to further enhance its attractiveness as an investment destination globally through the establishment of an open, transparent and predictable investment regime in the region. The improvement in the investment environment in ASEAN is being achieved through the implementation of the ASEAN Comprehensive Investment Agreement (ACIA), which (i) supports progressive liberalisation of existing investment restrictions in manufacturing, agriculture, fishery, forestry and mining and the services incidental to these sectors; (ii) significantly strengthens investment protection; and (iii) ensures transparency of investment laws, regulations and administrative guidelines (ASEAN, 2015). As a result, so many reform pressures promoted a wide range of changes in customs, taxation, investment, and business environment that are more transparent and equitable. Commitments on improving the investment environment and protection of intellectual property rights will attract the foreign investors into Vietnam, especially multinational corporations.

At the same time, domestic enterprises have the opportunity to boost investment in AEC countries. Thus, trade and investment between Vietnam and its members will be improved, opportunities will be available to attract huge capital inflows from ASEAN and other countries in which capital flows into retail sector. Lejour and Verheijden (2004), Mirza and Nicoletti (2004), Kox and Lejour (2005), and Lennon (2006) argued that trade liberalization from FTAs will promote the investment attractiveness. Based on this argument, we may identify a relationship between cognitive attitude of investment attractiveness and retail sector, such as:

$\mathrm{H}_{2}$ : There is a positive relationship between retailer's perception of the investment attractiveness from AEC and growth of retail market.

\subsection{The competitive pressure from AEC and growth of retail market}

Competition policy from the AEC has set a clear legal basis that does not accept incentives, and special treatment for any business. For ASEAN to be a competitive region with well-functioning markets, rules on competition will need to be operational and effective. The fundamental goal of competition policy and law is to provide a level playing field for all firms, regardless of ownership. The enforcement of competition rules that proscribe anti-competitive activities is an important way to facilitate liberalisation and a unified market and production base, as well as to support the formation of a more competitive and innovative region. This is an opportunity but also a challenge for small businesses in the retail sector. For SMEs with limited capital, backward technology and poor management practices, they may be bankrupt and excluded from the retail market (AEC, 2011). AEC will attract large retail investors from ASEAN countries into Vietnam market. The emergence of foreign retailers creates a strong competition between foreign corporations and domestic retailers. Many foreign retailers from Korea, Japan and Thailand have established distribution networks in Vietnam and are gaining higher market share in 
this high potential market. Competition between domestic and foreign retailers is fiercer (EU-Vietnam Business Network, 2018). Competition eliminates unprofessional retailers and weak competitiveness that risks leaving the market and giving room to qualified firms. The effective competition policy of AEC will help promote the development of retail market and create pressures for SMEs in the retail sector. These assumptions lead us to the third hypothesis:

$H_{3}$ : There is a positive relationship between retailer's perception of the competitive pressure from $A E C$ and growth of retail market.

2.6. The competitiveness of Small and medium enterprises in the ASEAN Economic Community and growth of retail market

SMEs are the backbone of ASEAN economies, and their development is essential for achieving long-term and sustainable economic growth. SMEs account for more than $96 \%$ of all enterprises and provide $50 \%$ to $85 \%$ of domestic employment in ASEAN member states. In addition, SMEs contribute $30 \%$ to $53 \%$ of gross domestic product (GDP) and produce between 19\% and 31\% of exports (AEC, 2011). The AEC framework for SMEs development in the ASEAN region aims to enhance the competitiveness of small and medium businesses by facilitating increased access to information, financing, technology and human resource and skills (ASEAN, 2010). As a result, ASEAN countries promoted the competitiveness and adaptability of SMEs. To enhance the competitiveness, Sato et al. (2013) shows that the strategy for developing SMEs is to make them become competitive and dynamic, wellnetworked horizontally and vertically, technologically innovated and well managed.

The studies of A.T.Kearney $(2015,2016)$, shown that the modern retailing channel of emerging markets developed through four stages: (1) Domestic retailers establish and gain the market share, and foreigners start to penetrating the market; (2) Foreign distributors speed up market expansion, while domestic retailers passively wait and observe market movements; (3) The "awakening" and accelerated expansion of domestic retailers; (4) Domestic retailers dominate the market, and foreign distributors withdraw from the market. Therefore, SMEs need to restructure and enhance competitiveness through improving productivity and innovative capabilities to meet the increased competition in the global market. Based on the above sudies, we consider a positive relationship between cognitive attitude of investment attractiveness and retail sector.

$H_{4}$ : There is a positive relationship between retailer's perception on the competitiveness of SMEs from AEC and growth of retail market.

\section{Research Methodology}

The research methodology combined qualitative and quantitative research through two phases, preliminary and formal researches. Preliminary research is conducted through qualitative analysis by in-depth interview and face-to-face discussions with retail experts. 
The purpose of this method is to adjust and supplement variables and measurement scale of the research concepts that are suitable to the particular situation of Vietnam retail market.

The scale of variables of the concepts in this study is based on the original scale of the previous studies. The free-trade scale reflects the belief in the benefits of free trade, adapted from Naylor et al. (2008), Deci et al. (1994), and Zhang et al. (2008, 2009), with six items to determine the benefits of free flows and trade facilitation in the region. The investment attractiveness scale shows how to promote a more favorable, transparent, and competitive investment environment in order to attract investors. It is adapted from Rusbult et al. (1998) and Raggio et al. (2009), reflecting the attractiveness and efficiency of investment, with six observational variables demonstrating the intention and capacity of the retailer. The competitive pressure scale drawn from the competition policy of the AEC is to determine the fair competition that does not accept incentives or special treatment for any business. It reflects competitive pressure and attitudes favoring fair and healthy business competition, as measured by six variables based on studies of Nenkov et al. (2008), Kumar et al. (1995), assessing perception on competitive environment. The scale of competitiveness of SMEs reflects the capacity and competence of the enterprises, with 6 variables adapted from Bearden et al. (2006) and La et al. (2000). The growth scale reflects the confidence and development in long term, adapted from Grayson et al. (2008), Bearden et al. (2006), including five items.

Based on the research concepts and scales of the previous studies, the qualitative research is conducted through in-depth interview with ten key people including two directors of supermarkets, two managers of convenience store chains, two managers of trade centers, two owners of retail companies, and two managers of grocery store chains in Ho Chi Minh City. As the result, five research concepts in the model are determined, namely: (1) free trade; (2) investment attractiveness; (3) competitive pressure; (4) competitiveness of SMEs; and (5) growth. The items of the research concepts are adjusted and adapted with the context of retail sector in Ho Chi Minh City. The quantitative questionnaire is designed with 29 items measured by a five-point Likert scale from (1) "strongly disagree" to (5) "strongly agree". The completed scale is shown in Table 1.

Research sample is 271 retailers including the retail enterprises, grocery stores, supermarkets, trade center and convenience store chains. Respondents are owners, directors, and managers. The research sample is selected by a convenient method (nonprobability sampling). Interviews are conducted by direct interviews and emails. Respondents are $43 \%$ female and $57 \%$ male. Business owners and shop owners account for $46 \%$ and managers $54 \%$ of the respondents. The grocery store group is the largest share of sample $(46 \%)$, followed by the group of retail enterprise $(35 \%)$, convenience store chains $(9,5 \%)$, supermarkets $(5,5 \%)$, and trade centers $(4 \%)$. 
Table 1.

Measurement scale of the main constructs

\begin{tabular}{lll}
\hline Item code & Observed variables & Sources \\
\hline Free Trade (FT) & & \\
FT1 & I believe that free trade will promote the retail sector much better & Naylor et al., \\
FT2 & I believe the retailers have a lot of imported items & $(2008) ;$ \\
FT3 & I think the prices of imported goods are cheaper because of & Deci et al., \\
& removing tariffs & Zhang et al., \\
FT4 & $\begin{array}{l}\text { I think that the retail sale will be dynamic with so many kinds of } \\
\text { commodity }\end{array}$ & (2008 2009) \\
FT5 & $\begin{array}{l}\text { I believe that trade facilitation will make the retail business more } \\
\text { convenient }\end{array}$ & \\
FT6 & elimination of non-tariffs &
\end{tabular}

Investment Attractiveness (IA)

IA1 I believe the transparent investment environment will push my retail business

Rusbult et al.,

IA2 I am interested in retail investment when the environment is transparent and favorable

(1998);

Raggio et al.,

IA3 I feel that there are many advantages to invest in retail business

(2009)

IA4 I will invest a lot of money in retail as the environment improves

IA5 I believe that retail will be better when the investment policy improved

IA6 I will invest a lot of effort in retailing

Competitive Pressure (CP)

CP1 With transparent competition policy, I believe the competitive environment will be healthy

Nenkov et al.,

CP2 I think that fair competition policy will create a good business environment

(2008);

Kumar et al.,

CP3 I believe the competitive pressure in retailing will increase

CP4 I think the competition will be fiercer

CP5 I always hold a positive attitude in favor of a healthy competitive environment

CP6 I feel confident to manage retail in a competitive environment 


\begin{tabular}{lll}
\hline Item code & Observed variables & Sources \\
\hline Competitiveness of SMEs (CO) & \\
CO1 & Improving competitiveness helps me to be confident in business & $\begin{array}{l}\text { Bearden et } \\
\text { al., (2006); }\end{array}$ \\
CO2 & $\begin{array}{l}\text { I believe that enhancing competitiveness will manage business } \\
\text { effectively }\end{array}$ & $\begin{array}{l}\text { La Guardia et } \\
\text { al., (2000) }\end{array}$ \\
CO3 & I believe in success in my retail business & \\
CO4 & I feel that I can continue to overcome challenges & \\
CO5 & I have a long-term retail investment plan & \\
CO6 & I will closely cooperate with manufacturers to improve my & \\
\hline competitiveness & \\
GR1 & I believe retail sales of goods and services will increase rapidly & Grayson et \\
GR2 & I think the modern retail channel will develop in the coming & $\begin{array}{l}\text { al., (2008); } \\
\text { Bearden et } \\
\text { al., (2006) }\end{array}$ \\
GR3 & years & \\
GR4 & I believe that retail spending will increase rapidly & \\
GR5 & I firmly believe that e-commerce in retail will grow in the future & \\
\hline & Overall, I believe that retail sectos will continue to grow & \\
\hline
\end{tabular}

\section{Research results}

\subsection{Data description}

Research data series are presented in Table 2. The mean values for all variables are ranging between 3.500 to 3.986. Free Trade has the highest mean (3.986), with standard deviation of 0.659; follows by Investment Attractiveness and Competitive Pressure with mean value of 3.852 and 3.777 respectively. Competitiveness of SMEs has the lowest mean of 3.500. This indicates that respondents have above average level of agreement towards the free trade, investment attractiveness, competitive pressure, competitiveness of SMEs, and growth of retail. All the variables score standard deviation lower than 1 in which indicates that the scores are clustered closely around the mean. 
Table 2

Descriptive Analysis

\begin{tabular}{lcc}
\hline Variables & Mean & Standard Deviation \\
\hline Free Trade (FT) & 3.986 & 0.659 \\
Investment Attractiveness (IA) & 3.852 & 0.714 \\
Competitive Pressure (CP) & 3.777 & 0.613 \\
Competitiveness of SMEs (CO) & 3.500 & 0.765 \\
Growth of Retail (GR) & 3.716 & 0.708 \\
\hline
\end{tabular}

\subsection{The reliability and factor analysis}

The reliability is concerned with an instrument's ability to measure consistently (Tavakol et al., 2011). The reliability test used was Cronbach's alpha. The reliability coefficient of Cronbach's alpha varies from 0 to 1 . If the Cronbach's alpha coefficient is closer to 1.0, the consistency of the items would be higher. Cronbach's alpha is the most widely used measure of reliability when multiple-item measures are used. Cronbach's alpha has been reported to show the internal consistency for the scales used for this research. Internal consistency refers to the inter-relatedness of the items in the scale. The reliability of the items must have the Cronbach's alpha coefficient higher than 0.6 (Churchill, 1979), and corrected item-total correlation of higher than 0.3 (Nunnaly \& Burtien, 1994). The results shown that two observation variables of the competitive pressure (CP1 and CP2) have correlation coefficients of 0.038 and 0.125 respectively; two items of competitiveness (CO5 and CO6) with Cronbach's alpha coefficients are lower than 0.6. Hence, four observed variables were deleted. The remaining observed variables have Cronbach's alpha value from 0.675 to 0.840 , so all items' reliability is achieved. The internal consistency of all variables (free trade, investment attractiveness, competitive pressure, competitiveness, and growth) indicated that twenty five items are used for exploratory factor analysis. The result of reliability tests is presented in Table 3.

The exploratory factor analysis (EFA) is used in the principal component analysis method and variance maximization rotation. At the first rotated round of 20 independent variables, four components are extracted, and three items (FT6, IA5, IA6) are deleted because the rotated factor loadings are less than 0.5 (Bagozzi, 1994). The results of EFA shows that KMO and Bartlett's Test is 0.823 (sig: 0.000); the number of factors extracted is 4, consistent with the hypothesis of the scale component; the Eigenvalues are 1.137; the cumulative variance is $58.49 \%$, and all factor loadings are greater than 0.5 . No items have been deleted as the values have fulfilled the requirement of over 0.50 (Bagozzi et al., 1988). The results of exploratory factor analysis of the dependent variable (growth of retail), with varimax rotation of principal component method shown that only one component is extracted, eigen-value of 3.061 ; the cumulative variance contribution rate is $61.21 \%$. The KMO 
coefficient is 0.723; and Barlett's test of sphericity has high significance (sig. $=0.000)$. All five factor loadings are higher than 0.7 , and Cronbach's alpha is 0.840 . Thus, scales of research concepts are accepted and are used for multiple linear regression analysis.

Table 3

Reliability and validity of measurement constructs

\begin{tabular}{lcccc}
\hline Variables & $\begin{array}{c}\text { No of } \\
\text { items } \\
\text { before } \\
\text { test }\end{array}$ & $\begin{array}{c}\text { No of } \\
\text { items } \\
\text { after } \\
\text { test }\end{array}$ & $\begin{array}{c}\text { Cronbach's } \\
\text { Alpha }\end{array}$ & $\begin{array}{c}\text { Factor loadings } \\
\text { (from lowest to } \\
\text { highest) }\end{array}$ \\
\hline Free Trade (FT) & 6 & 5 & 0.836 & $0.542-0.803$ \\
Investment Attractiveness (IA) & 6 & 4 & 0.791 & $0.749-0.836$ \\
Competitive Pressure (CP) & 6 & 4 & 0.768 & $0.741-0.796$ \\
Competitiveness of SMEs (CO) & 6 & 4 & 0.675 & $0.625-0.712$ \\
Growth of Retail (GR) & 5 & 5 & 0.840 & $0.758-0.796$ \\
\hline
\end{tabular}

\subsection{Correlation analysis}

Correlation coefficients are used to identify the level of close relationship between two or more variables. The absolute value of correlation coefficient is close to 1 which means the variables have a tight linear correlation. If the correlation is lower than 0.85 , it means discriminant validity exists between two variables (John \& Martinez, 2000). The results in Table 4 show that the correlation value of each pair between constructs is from 0,111 to 0,694 . This means the main constructs gain discriminant validity. Thus, the measurement scale meets the requirement of measuring different constructs.

\section{Table 4}

Pearson Correlations Matrix

\begin{tabular}{lccccc}
\hline & \multicolumn{5}{c}{ Correlations } \\
\hline Free Trade (FT) & FT & IA & CP & CO & GR \\
\cline { 2 - 6 } Investment Attractiveness (IA) & 1 & & & \\
Competitive Pressure (CP) & 0.694 & 1 & & & \\
Competitiveness of SMEs (CO) & 0.111 & 0.198 & 1 & 0.558 & 1 \\
Growth of Retail (GR) & 0.403 & 0.430 & 0.101 & 1 & \\
\hline
\end{tabular}

Note: Correlation is significant at the 0.01 level (2-tailed); $(\mathrm{n}=271)$ 


\subsection{Regression analysis}

The result in Table 5 shows that the relationship between free trade and growth of retail has been found to be significant at $10 \%$ confident level with positive beta value at 0.341 . This indicates that the retailer's perception towards free trade from AEC has significant positive effect on retail growth. Therefore, hypothesis 1 is accepted. The result also shows that investment attractiveness has significant positive relationship (beta value $=0.262$ ) at confident level of $10 \%$ with growth of retail. Thus, hypothesis 2 is substantiated. Similarly, the relationship between competitive pressure and growth of retail was found to be significant $(\mathrm{sig}=.000)$ at $10 \%$ significant level with positive beta at 0.216 . This indicates that competitive pressure has significantly positive relationship with retail growth. Thus, the third hypothesis is accepted. The findings of regression analysis show that there is a relationship between competitive pressure and growth of retail with positive beta at 0.184 . Result after testing the hypotheses states that $\mathrm{H} 1, \mathrm{H} 2, \mathrm{H} 3$ and $\mathrm{H} 4$ are significantly supported. The adjusted $\mathrm{R}$ square of regression model is 0.516 , it means that free trade, investment attractiveness, competitive pressure, and competitiveness of SMEs being studied can explain $51.6 \%$ of the variation on retail growth. This meant that result from this study with $51.6 \%$ explanation towards the growth of retail sector and the remaining $48.4 \%$ should be explained by other factors.

The $F$ value $(F=73.003)$ with significance at $p$-value lower than 0.001 indicates that the research model is very suitable for the collected data, and there is at least one independent variable having linear relationship with the dependent variable. The VIF indexes are from 1.043 to 1.984 (less than 10) and Tolerance indicators are higher than 0.1 (from 0.479 to 0.859 ). This result indicates very low multicollinearity among the variables.

\section{Table 5}

Regression analysis

\begin{tabular}{|c|c|c|c|c|c|c|c|}
\hline & \multicolumn{2}{|c|}{$\begin{array}{c}\text { Unstandardized } \\
\text { Coefficients }\end{array}$} & $\begin{array}{c}\text { Standardized } \\
\text { Coefficients }\end{array}$ & \multirow[b]{2}{*}{$\mathrm{T}$} & \multirow[b]{2}{*}{ Sig. } & \multicolumn{2}{|c|}{ Collinearity Statistics } \\
\hline & B & $\begin{array}{l}\text { Std. } \\
\text { Error }\end{array}$ & $\beta$ & & & Tolerance & VIF \\
\hline (Constant) & 0.393 & 0.286 & & 1.378 & 0.009 & & \\
\hline FT & 0.341 & 0.061 & 0.362 & 6.404 & 0.000 & 0.504 & 1.984 \\
\hline IA & 0.262 & 0.075 & 0.275 & 6.996 & 0.003 & 0.794 & 1.088 \\
\hline $\mathrm{CP}$ & 0.216 & 0.044 & 0.227 & 5.375 & 0.000 & 0.859 & 1.043 \\
\hline $\mathrm{CO}$ & 0.184 & 0.061 & 0.191 & 5.685 & 0.000 & 0.479 & 1.260 \\
\hline \multicolumn{8}{|c|}{ Adjusted R-Square $=0.516$} \\
\hline \multicolumn{8}{|l|}{$\mathrm{F}=73.003$} \\
\hline Sig $=0.000$ & & & & & & & \\
\hline
\end{tabular}




\section{Conclusion and managerial implication}

\subsection{Conclusion}

The results reveal that retailer's perception of the impact of AEC which focuses on four factors, (1) free trade, (2) investment attractiveness, (3) competitive pressure, and (4) competitiveness of SMEs has significant positive relationship with growth of retail sector. In other words, if retailer can take advantages of the AEC, it will push the growth of retail market. The free trade from AEC has the highest impact on retail growth and the competitiveness of SMEs has the lowest impact. Each factor has different level of impact on the growth of retail sector, as fllows:

The standardized regression coefficient for free trade is highest $(\beta=0.362)$. This indicates that AEC will create a common market with free trade in goods and services. Local retailers should take the advantages of the removal of tariff and non-tariff barriers to import quality goods at competitive prices.

The standardized regression coefficient for investment attractiveness is high $(\beta=0.275)$. In other words, investment attractiveness has a strong impact on retail. Once the investment environment is improved, it will motivate domestic and foreign retailers to focus on resources, expand business scale, and develop distribution networks.

The standardized regression coefficient for the competitive pressure factor is also high $(\beta=0.227)$. It means that local retailers are faced with high competitive pressure from foreign companies.

The factor of motivation to develop SMEs has standardized regression coefficient of 0.191. It reflects that AEC strongly support local retailers to improve competitiveness.

\subsection{Managerial implication}

Based on the results and findings, some recommendations are proposed in order to contribute to the development of Vietnam retail market:

First, the country should leverage and exploit the advantages of free trade process. The retailers should import the high quality goods with competive price from the ASEAN countries, and exploit the trade facilities to penetrate into the retail supply chain. The modern and traditional channel retailers should restructure the product-line, diversify sources, expand the networking with production and trade, and build up the effective retail supply chains.

The government should build effective mechanisms for monitoring the quality and level of hygiene and safety of goods through retail distribution channels. It is necessary to set up a standard system to meet the requirements of AEC countries, as well as to compete with the imported goods with poor quality from inside and outside the block.

Second, the country should create favorable conditions to encourage local and foreign investments in the retail sector: To attract the investors in the retail sector, the policy makers should consider the following aspects: (1) Build up the master plans for developing the retail 
distribution system, adjust and correct the shortcomings of the previous plans, and restrict the spontaneous distribution system. Government should encourage the investment in trade infrastructure by the form of socialization; (2) Improve the transparency in the licensing process, and standardize the criteria of the economic need test (ENT) applied to foreign investors; (3) Create favorable conditions to encourage the local private sector and foreigners to invest in modern and traditional retail channels.

Third, the country should motivate SMEs to improve their competitiveness and sustainability in the retail market: To enhance the advantages, SMEs should focus on: (1) Learning the advanced management and modern business methods of the foreign retailers to improve their own competitive advantage; (2) Restructuring and building long-term business strategies; (3) Continuing to invest in rapidly expanding retail network, exploiting the existing premises to maintain and grow market share; (3) Investing in logistics and information technology systems to reduce operating costs, improving the efficiency and effectiveness of operating and management system; (4) Strengthening networking with domestic enterprises in the form of cooperation, joint ventures, franchising; (6) Developing the traditional retail market.

In general, the research indicated that retailer's perceptions of the impact of the AEC based on four factors of free trade, investment attractiveness, competitive pressure, and competitiveness of SMEs on retail growth. The results will be better if more factors will be considered. This is a matter for further research

\section{References}

AEC (2011). ASEAN Economic Community Handbook for Business. The ASEAN Secretariat, Jakarta, Indonesia. Retrieved from http://www.asean.org/wp-content/uploads/2011/11/AEC-Handbook.pdf

AEC (2015). ASEAN Economic Community 2015: Progress and Key Achievements. The ASEAN Secretariat, Jakarta, Indonesia. Retrived from https://www.asean.org/wpcontent/uploads/images/2015/November/media-summary-

ABIS/AEC\%202015\%20Progress\%20and\%20Key\%20Achievements_04.11.2015.pdf

ASEAN (2015). ASEAN Ecnomic Community Blueprint 2025. The ASEAN Secretariat, Jakarta, Indonesia.

Retrieved

from

http:/ / www.asean.org/storage/images/2015/November/aec-page/AEC-Blueprint2025-FINAL.pdf

ASEAN (2010). ASEAN Strategic Action Plan for SME Development 2010-2015. The ASEAN Secretariat, Jakarta, Indonesia. Retrieved from https://www.asean.org/storage/ images/archive/SME/SPOA-SME.pdf

A.T.Kearney, (2017). The 2017 Global Retail Development Index, The Age of Focus. Retrieved from: https://www.atkearney.com/documents/10192/12766530/ The+Age+of+Focus \%E2\%80\%93The+2017+Global+Retail+Development+Index.pdf/77 0c5a53-d656-4b14-bc6c-b0db5e48fdc1

A.T.Kearney, (2016). The 2016 Global Retail Development Index, Global Retail Expansion at a Crossroad. Retrieved from https:/ / www.atkearney.com/documents/10192/8226719/ 
Global+Retail+Expansion+at+a+Crossroads\%E2\%80\%932016+GRDI.pdf/dc845ffc-fe284623-bdd4-b36f3a443787

A.T.Kearney, (2010). GRDI: A 10-Year Retrospective, The Global Retail Development Index, Lessons learned from a decade of retail expansion. Retrieved from https://www.atkearney.com/documents/10192/481787/GRDI-A_10Year_Retrospective.pdf

Bagozzi, R. P., \& Yi, Y. (1988). On the evaluation of structuralequation models. Journal of the Academy of Marketing Science, 16(1), 74-94.

Baldwin, R. (1989). The growth effects of 1992. Economic policy, 4(9), 247-281.

Baier, S., \& Bergstrand, J. (2002). On the Endogeneity of International Trade Flows and Free Trade Agreements. American Economic Association annual meeting.

Baier, S., \& Bergstrand, J. (2007). Do Free Trade Agreements Actually Increase Members'International Trade? Journal of International Economics, 71(1), 72-95.

Barry, B., Joel, R., \& Patrali, C (2018). Retail Management: A Strategic Approach. 13 th ed, Pearson.

Bearden, William, O., Bruce, M., \& Jennifer, L. N. (2006), A Measure of Long-Term Orientation: Development and Validation. Journal of the Academy of Marketing Science, 34(3), 456-467.

Bennett, R. C., \& Cooper, R. G. (1981). The misuse of marketing- an american tradegy. Business Horizons, 24(5), 1-61.

Carrere, C. (2006). Revisiting the effects of regional trade agreements on trade flows with proper specification of the gravity model. European Economic Review, 50(2), 223-247.

Cheong, I. (2013). Negotiations for the Trans-Pacific Partnership agreement: Evaluation and implications for East Asian regionalism. ADBI Working Paper 428. Tokyo: Asian Development.

Churchill, G. A. J. (1979). A paradigm for developing better measures of marketing constructs. Journal of Marketing Research, 16(2), 64-73.

Corden, W. (1972). Economies of Scale and Customs Union Theory. Journal of Political Economy, 80(3), 465-475.

Deci, E. L., Haleh, E., Brian, C. P., \& Dean, R. L. (1994), Facilitating Internalization: The SelfDetermination Theory Perspective, Journal of Personality, 62(1), 119-142.

EU-Vietnam Business Network, (2018). Vietnam's Distribution and Retail Channels. Research Report. European Union. Retrieved from http://www.ccifv.org/singlenews/n/vietnams-distribution-and-retail-channels-report-evbn/

Francois, J., (2001). The Next WTO Round: North South Stakes in New Markets Access Negotiations. Adelaide: Centre for International Economics Studies.

Grayson, K., Devon, J., \& Der-Fa, R. C. (2008), Is Firm Trust Essential in a Trusted Environment? How Trust in the Business Context Influences Customers, Journal of Marketing Research, 45(2), 241-256.

Grunfeld, L. A., \& Moxnes, A. (2003). The Intangible Globalization: Explaining the Patterns of International Trade in Services. Discussion Paper.

Itakura, K., \& Lee, H. (2012). Welfare changes and sectoral adjustments of Asia-Pacific countries under alternative sequencings of free trade agreements. Global Journal of Economics, 1(02), 1250012. 
John, O. P., \& Benet-Martinez, V. (2000). Measurement: Reliability, construct validation, and scale construction. Handbook of research methods in social and personality psychology. Cambridge: Cambridge University Press.

Kimura, F., \& Lee, H. H. (2006). The gravity equation in international trade in services. Review of World Economics, 142(1), 92-121.

Kox, H., \& Lejour, A. M. (2005). Regulatory Heterogeneity as Obstacle for International Services Trade (49). The Hague: CPB Netherlands Bureau for Economic Policy Analysis.

Kotler , P., \& Armstrong, G (2012). Principles of Marketing, 14th ed. Pearson, New Jersey.

Kumar, N., Lisa, K. S., \& Jan-Benedict, E. M. (1995). The Effects of Perceived Interdependence on Dealer Attitudes, Journal of Marketing Research, 32(3), 348-356.

La, G., Jennifer, G., Richard, M. R., Charles, E. Co., \& Edward L. D. (2000). Within-Person Variation in Security of Attachment: A Self-Determination Theory Perspective on Attachment, Need-Fulfillment and Well-Being, Journal of Personality and Social Psychology, 79(3), 367-384.

Lennon, C., (2006). Trade in Services and Trade in Goods: Differences and Complemetarities. Conference of the European Trade Study Group. Vienna.

Lejour, A., \& de Palva Verheijden, J. W. (2004). Services trade within Canada and the European Union. Discussion Paper 42. The Hague: Centraal Plan Bureau.

McNair, M. P., (1958). Significant trends and developments in the postwar period. In A. B. Smith (Ed.), Competitive distribution in a free, high-level economy and its implications for the University (1-25). Pittsburgh: University of Pittsburgh Press.

Mirza, D., \& Nicoletti, G. (2004). What is so special about trade in services? Research paper 2004/02. Nottingham: Leverhulme Centre for Research on Globalisation and Economic Policy, University of Nottingham.

Naylor, G., Susan, B. K., Julie, B., \& Eric, Y. (2008). Using Transformational Appeals to Enhance the Retail Experience, Journal of Retailing, 84(1), 49-57.

Nenkov, G. Y., Jeffrey, I, J., \& John, H. (2008). Considering the Future: The Conceptualization and Measurement of Elaboration on Potential Outcomes, Journal of Consumer Research, 35(1), 126-141.

Nguyen, A. T. (2012). Assessing the Impact of Vietnam's Integration under AFTA and VJEPA on Vietnam's Trade Flows, Gravity Model Approach. Yokohama Journal of Social Sciences, 17(2), 137-148.

Nguyen, D. T., \& Nguyen, T. T. H. (2015). The Impacts of TPP and AEC on the Vietnamese Economy: Macroeconomic Aspects and the Livestock Sector. The gioi Publishing Company. Ha Noi. Retrieved from http://vepr.org.vn/upload/533/20160105/TPP\%20\%20Eng.pdf

Nguyen, A. T., Vu, T. H., Vu, V., \& Le, T. X. (2015). The impact of the ASEAN Economic Community to Vietnam trade. VNU Journal of Science - Economics and Business, 31(4), 39-50.

Nunnally, J., \& Bernstein, I. H. (1994). Pschychometric Theory, $3^{\text {rd }}$ ed., McGraw- Hill, New York.

Park, S. C., (2002). Measuring Tariff Equivalents in Cross-Border Trade in Services. Korea Institute for International Economic Policy Working Paper 02-15. Seoul

Petri, P. A., Plummer, M. G., \& Zhai, F. (2012). The Trans-Pacific Partnership and AsiaPacific Integration: A Quantitative Assessment. Peterson Institute Press: All Books. 
Plummer, M., Cheong. D., \& Hamanaka, S. (2010). Methodology for Impact Assessment of Free Trade Agreements. Philippines: Asian Development Bank.

Plummer, M. (2007). Best Practices in Regional Trading Agreements: An Application to Asia. The World Economy, 30(12), 1771-1796.

PricewaterhouseCoopers, (2015). 2015-2016 Outlook for the Retail and Consumer Products sector in Asia. PWC report. Retrieved from: https://www.pwc.com/id/en/publications/assets/cips/2015-16-outlook-for-the-retail-andconsumer-products-sector-in-asia.pdf

Raggio, R. D., \& Judith, A. F. (2009). Gratitude Works: Its Impact And The Mediating Role of Affective Commitment In Driving Positive Outcomes. Journal of Academy of Marketing Science, 37(4), 455-469.

Rusbult, C. E., Martz, J. M., \& Agnew, C. R. (1998), "The Investment Model Scale: Measuring Commitment Level, Satisfaction Level, quality of Alternatives, and Investment Size" Personal Relationships, 5(4), 357-391.

Rusbult, C. E. (1980), Commitment and Satisfaction In Romantic Associations: A Test of The Investment Model. Journal of Experimental Social Psychology, 16(2), 172-186.

Sato, Y. (2015). Development of Small and Medium Enterprises in the ASEAN Economics. Japan Center for International Exchange.

Tavakol, M., \& Dennick, R. (2011). Making sense of Cronbach's alpha. International Journal of of Medical Education, 2, 53-55.

Todsadee, A., Kameyama, H., \& Lutes, P. (2012). The implications of trade liberalization on TPP countries' livestock product sector. Technical Bulletin of the Faculty of Agriculture of Kagawa University, 64, 1-6.

Tulus., T. (2011), Development of Small and Medium Enterprises in ASEAN countries. New Delhi. Readworthy Publications.

Urata, S., \& Okabe, M. (2010). The impacts of free trade agreements on trade flows: An application of the gravity model approach. In Free Trade Agreements in the Asia Pacific. 195-239.

Zhang, Y., \& Adwait, K. (2009). The Impact of Accessible Identities on the Evaluation of Global versus Local Products. Journal of Consumer Research, 36(3), 524--537. 